[Agr. Biol. Cnem., Vol. 31, No. 12, p. 1466 1473, 1967]

\title{
Bacteriophages of L-Glutamic Acid-Producing Bacteria
}

\section{Part VIII. Growth Characteristics of Brevibacterium Phages*}

\author{
By Toshikazu OKI and Asaichiro OzAKI \\ The Central Research Laboratories, Sanraku-Ocean Co., Ltd., Fujisawa \\ Received July 7, 1967
}

\begin{abstract}
The growth characteristics of phages were investigated with the four phages, active on Brevibacterium lactofermentum, which were selected from the respective serological groups, namely, P465 (group I), P468II (group II), Ap85III (group III) and P4 (group IV).

The adsorption rate of the phages, P465 and P468II, on the host bacteria was low, whereas that of the phages, Ap85III and P4, was higher. The adsorption rate constants for the four phages were respectively calculated at $2.02 \times 10^{-10}, 1.87 \times 10^{-10}, 4.32 \times 10^{-10}$ and $3.15 \times 10^{-10} \mathrm{~cm}^{3}$ per minute, at $30^{\circ} \mathrm{C}$ in $\mathrm{G}_{5} \mathrm{~B}_{2}$ medium. With reference to the ionic environment for adsorption, the phages, $\mathrm{P} 465$ and Ap85III, specifically required either for $\mathrm{Ca}^{++}$ or $\mathrm{Mg}^{++}$; the phage $\mathrm{P} 468 \mathrm{II}$, for both; and the phage $\mathrm{P} 4$, for neither.

The growth characteristics of these phages were examined by the one-step growth experiment. The latent periods of the phages were 50,53,57 and 47 minutes, respectively; and the corresponding average burst sizes were about 98, 31, 145 and 126 . The growth of the phage $\mathrm{P} 4$ was completely suppressed at above $34^{\circ} \mathrm{C}$, although the host bacteria and the other three phages were capable of the full growth at that temperature.
\end{abstract}

\section{INTRODUCTION}

The first step in the growth cycle of phages is the adsorption onto their host cells. Since the step is the most accessible to observation, it has been more thoroughly studied than the subsequent steps. The studies on effects of environmental factors and of the physiological state of the host cell on the rate of phage adsorption have contributed greatly to understanding of the phage-and-host cell relationship. After adsorption of a phage to its host cell, a certain period of time elapses before the cell lyses, liberating phage progeny. The time interval in this is most conveniently measured by means of the one-step growth experiment as described by Ellis and Delbrück."

* This work was presented at the Annual Meeting of the Agricultural Chemical Society of Japan, in April of 1966. I) E. L. Ellis and M. Delbrück, J. Gen. Physiol.,
22, 365 (1939).
With respect to the phages of L-glutamic acid-producing bacteria, Seto et al. ${ }^{2)}$ discussed briefly the growth of the phages, P1, P2, P3, $\mathrm{P} 4$ and $\mathrm{P} 5$, of Mic. ammoniaphilum. The previous data on the adsorption of phages to host cells and one-step growth experiments, in respect to the four phages from serological group $I,{ }^{31}$ are unsatisfactory in accuracy, for above experiments had been carried out without using antiphage serum. This paper therefore takes them up again with more or less full account.

The present study was undertaken, first, to elucidate the aspects and the ionic requirements of the phages for adsorption to the host cell, Brevibacterium lactofermentum; and, second, to determine quantitatively by means of the

2) S. Seto, T. Osawa and S. Yamamoto, J. Agr. Chem. Soc. Japan, 39, 48 (1965).

3) T. Oki, T. Matsui, K. Akahoshi and R. Harada, J. Agr. Chem. Soc. Japan, 38, 376 (1964); Amino Acid and Nucleic Acid, 9, 53 (1964). 
one-step growth technique two important characteristics of the phage multiplication, the latent period of intracellular growth and the burst sizes.

\section{MATERIALS AND METHODS}

Phages and bacteria. The four phages selected from the respective serological groups, P465 (group I), P468II (group II), Ap85III (group III) and P4 (group IV), and the host strains, YO2 for the first three and and 468-5SMr for the last, were used.4)

The host cells employed in the adsorption and onestep growth experiments were prepared as follows: $10 \%$ inoculum of the overnight host-bacterial culture in G-medium was added to a fresh G-medium, and the said culture was then incubated for 6 hours at $30^{\circ} \mathrm{C}$. The cells in the logarithmic growth phase were harvested by centrifugation and resuspended in the adequate medium.

The dialysed phages as reported previously4) were used to determine the ionic requirements for adsorption of the phages to the host cell.

Assay of phages and bacteria. The phages and bacteria were assayed by the same methods as described in the previous paper. ${ }^{3}$ ) With phage P4, labile to temperature, the method was partially modified to paevent the phage from being exposed to high temperature; i.e., a diluted phage suspension $(0.1 \sim 0.2 \mathrm{ml})$ was dropped on a basal layer medium, about $2 \mathrm{ml}$ soft agar containing host cell was overlayed thereupon, and both were mixed well.

Antiphage sera. The anti-phage sera were prepared by the method described in the preceding paper. ${ }^{4)}$ The $K$ values of the antisera against the above four phages were $15,75,50$ and 150 , respectively.

Media. G-medium as previously reported ${ }^{4)}$ was used for growing bacteria and phages. The media used for the adsorption of the phages to their host cell and for the one-step growth experiments were as follows: $G_{5} B_{2}$ or $G_{5} B_{50}$ medium consisting of $50 \mathrm{~g}$

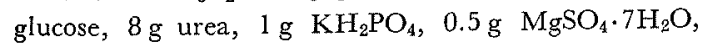
$4 \mathrm{~g}$ corn steep liquor, $2 \mathrm{mg} \mathrm{Mn^{++ } , 2 \mathrm { mg } \mathrm { Fe }} \mathrm{m}^{++}, 100 \mu \mathrm{g}$ thiamine. $\mathrm{HCl}, 2$ or $50 \mu \mathrm{g}$ biotin, respectively, and $1,000 \mathrm{ml}$ distilled water; and $\mathrm{S}$ medium consisting of $100 \mathrm{~g}$ glucose, $8 \mathrm{~g}$ urea, $1 \mathrm{~g} \mathrm{KH}_{2} \mathrm{PO}_{4}, 1 \mathrm{~g} \mathrm{~K} \mathrm{HPO}_{4}$, $0.5 \mathrm{~g} \mathrm{MgSO}_{4} \cdot 7 \mathrm{H}_{2} \mathrm{O}, 100 \mu \mathrm{g}$ thiamine $\cdot \mathrm{HCl}, 2 \mu \mathrm{g}$ biotin,

4) T. Oki, T. Matsui and A. Ozaki, This Journal, 31, 861 (1967).
$2 \mathrm{~g}$ casamino acid and $1,000 \mathrm{ml}$ distilled water. These media were autoclaved for 15 minutes at $115^{\circ} \mathrm{C}$. Dilutions of the phages, and experiments on the ionic requirements in the phage adsorption followed the routine procedures with the dilution buffer $(0.01 \mathrm{M}$ Tris-HCl buffer containing $5 \mathrm{~g} \mathrm{NaCl}, \quad 0.05 \mathrm{~g}$ $\mathrm{MgSO}_{4} \cdot 7 \mathrm{H}_{2} \mathrm{O}, 0.05 \mathrm{~g} \mathrm{CaCl}_{2} \cdot 2 \mathrm{H}_{2} \mathrm{O}$ and $0.1 \mathrm{~g}$ casein in $1,000 \mathrm{ml}$, at $\mathrm{pH} \mathrm{7.4)}$.

Adsorption. The procedures for the experiments on the adsorption and the one-step growth are comparable to those given by Adams. ${ }^{5}$. The bacterial suspension (about $5 \times 10^{8}$ cells $/ \mathrm{ml}$ in $\mathrm{G}$ medium) was brought to $30^{\circ} \mathrm{C}$, when the phages were added to give a final concentration of $5 \times 10^{5}$ plaque-forming units (PFU) per $\mathrm{ml}$, and both were mixed well. A $0.1 \mathrm{ml}$ samples of the mixture was removed at the 5-minute intervals and immediately diluted to $1: 100$ with chilled dilution buffer to prevent further adsorption. The diluted samples were then centrifuged at $10,000 \mathrm{r} . \mathrm{p} . \mathrm{m}$. for 5 minutes at $0^{\circ} \mathrm{C}$ to separate unadsorbed free phages from the adsorbed. The aliquot of the supernatant fluid was accurately assayed on the unadsorbed free phages. The adsorbed phages were estimated by the difference between the initial and the free phage titers at the sampling time.

Another procedure which determined the number of infected bacteria was carried out by using antiphage serum. In the preliminary test, it was confirmed that the antiphage serum had no effect upon the ability of infected bacteria to produce plaques, provided the antiserum was diluted so that its concentration on the plate did not affect the plaque formation.

The multiplicity of infection was 0.001 , as above. After mixing bacteria with the phages, $0.1 \mathrm{ml}$ of the mixture was removed at one time and at the 5-minute intervals and diluted to $1: 10$ in the antiphage serum by an approximate dilution as calculated from the $K$ value, to inactivate $99 \%$ of the free phages in 5 minutes. After 5 minutes, the sample was further diluted to remove the antiserum, and was plated to determine the number of infected bacteria, which, at each interval, was subtracted from the total phage input in the adsorption tube, to give the amount of the remaining unadsorbed phage.

The adsorption rate constant, $K$ ( $\mathrm{cm}^{3}$ per min), was calculated from the following equation. ${ }^{6)}$ :

5) M. H. Adams, "Bacteriophages," Interscience Publishers, N. Y., 1959, p. 466.

6) A. P. Krueger, J. Gen. Physiol., 14, 493 (193I). 


$$
K=2.3 /(B) t \times \log P_{0} / P
$$

in which $P_{0}$ stands for phage titer at zero time; $P$, for the phage not adsorbed at a specific time $(t) ;(B)$, for concentration of bacteria by number of cells per $\mathrm{ml}$. Any deviation from the routine techniques is given in the results.

One-step growth experiment. The detailed account of the one-step growth experiment is as follows: A one-tenth $\mathrm{ml}$ of a phage solution containing $1 \times 10^{7}$ PFU per $\mathrm{ml}$ was mixed with $0.9 \mathrm{ml}$ of bacterial susspension containing $1 \times 10^{8}$ cells per ml (M.O.I.= about 0.01). After adsorption of the phage in 10 $\min , 0.5 \mathrm{ml}$ of the mixture was added to $4.5 \mathrm{ml}$ of diluted antiserum, and $99 \%$ of the unadsorbed free phages was neutralized for $5 \mathrm{~min}$, at $30^{\circ} \mathrm{C}$. The neutralized mixture was then diluted to $1: 10$ in medium, and, immediately after that, $1 \mathrm{ml}$ of the diluted solution was added to $9 \mathrm{ml}$ of a fresh medium in the first tube. Successively, $1 \mathrm{ml}$ from the first tube was added to $9 \mathrm{ml}$ of another fresh medium in the second tube. These tubes were incubated at $30^{\circ} \mathrm{C}$ in the monod-shaker, and $0.1 \mathrm{ml}$ samples from the first and second tubes were plated by the doublelayer, technique, at 2-to-5-minute intervals. After incubation at $30^{\circ} \mathrm{C}$ overnight, the plaques were counted.

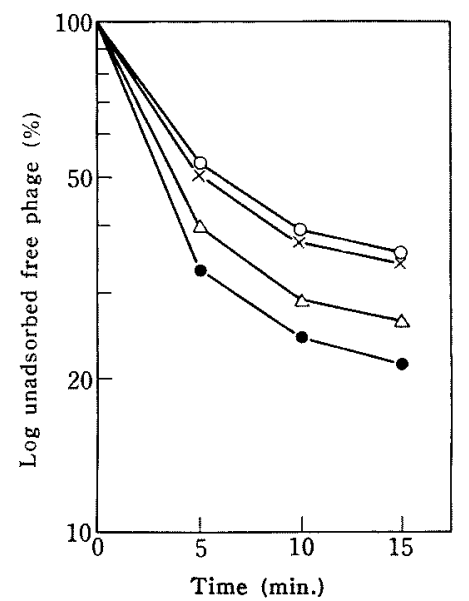

FIG. 1. Adsorption of Four Phages onto Host Bacteria.

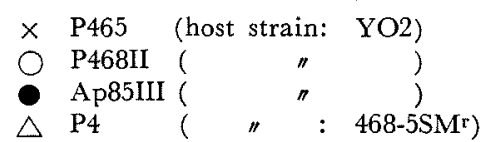

Incubation was carried out at the $P / B$ ratio of 0.001 in $\mathrm{G}_{5} \mathrm{~B}_{2}$ medium at $30^{\circ} \mathrm{C}$.

\section{RESULTS AND DISCUSSION}

Effect of medium on adsorption of phages. The adsorption curves of the four phages in $\mathrm{G}_{5} \mathrm{~B}_{2}$ medium at $30^{\circ} \mathrm{C}$ are shown in Fig. 1 . The phages, P4 and Ap85III, were adsorbed on the host bacteria at the rate of more than 70 per cent in 15 minutes; while the phages, P465 and P468II, were slowly adsorbed at the rate of 50 per cent in 5 minutes and about 65 percent in 15 minutes. The adsorption of P465 in this experiment was slightly slower than that indicated in the previous paper; ${ }^{3 \prime}$ it is considered, however, to be conditional differences on which the experiments have been proceeded.

The adsorption rate of the phage particles was found to be roughly proportional to the concentration of the phage and bacteria. Considering the fact that the number of added bacterial cells greatly exceeds the number of the phage (M.O.I. $=0.001)$ in these experiments, the adsorption process follows the formula of the first order reaction with respect to the concentration of the phage remaining, unadsorbed, in the medium. In this case, the $K$ values for the phages, P465, P468II, Ap85III and P4, were calculated to be $2.02 \times$ $10^{-10}, 1.87 \times 10^{-10}, 4.32 \times 10^{-10}$ and $3.15 \times 10^{-10}$ $\mathrm{cm}^{3}$ per minute, respectively. On the other hand, the $K$ values vary in a wide range with various types of medium used (Table I). From the above results, the complete medium like $\mathrm{G}_{5} \mathrm{~B}_{2}$ is definitely better than the defined

TABLE I. EFFeCt of Medium ON ADSORPTION Rate Constant of Phages

\begin{tabular}{lcccc} 
Medium & \multicolumn{4}{c}{$K\left(\times 10^{-10}\right)$} \\
Phage & $\begin{array}{c}\text { S } \\
\text { (defined } \\
\text { media) }\end{array}$ & $\mathrm{G}_{5} \mathrm{~B}_{2}$ & $\begin{array}{c}\mathrm{G}_{5} \mathrm{~B}_{2} \text { plus } \\
0.01 \%\end{array}$ & $\begin{array}{c}\text { Bouil- } \\
\mathrm{CaCl}_{2}\end{array}$ \\
P465 & 0.72 & 2.02 & 4.62 & 1.68 \\
P468II & 0.74 & 1.87 & 3.12 & 1.49 \\
Ap85III & 1.00 & 4.32 & 7.15 & 2.70 \\
P4 & 2.13 & 3.15 & 2.98 & 2.48
\end{tabular}

Phage-host mixture $(P / B=0.001)$ was incubated in the monod-shaker at $30^{\circ} \mathrm{C}$.

The $K$ value is an average of at least two data. 
medium for the adsorption of the phages, P465, P468II and Ap85III; and the adsorption of the phages was accelerated by the supplement of 0.01 per cent $\mathrm{CaCl}_{2}$ to $\mathrm{G}_{5} \mathrm{~B}_{2}$ medium. On the contrary, the adsorption of the phage P4 was similar in all these media. Therefore, it is supposed that those three phages require the ionic environment or organic cofactors for adsorption, as described in many reports. ${ }^{7 \sim 14}$

With respect to the adsorption of the phages of L-glutamic acid-producing bacteria, Seto et al. ${ }^{2)}$ discussed that the phages, P1, P2, P3, $\mathrm{P} 4$ and $\mathrm{P} 5$, were adsorbed onto Mic. ammoniaphilum-A at the $K$ values of 5.2 to $7.2 \times 10^{-10}$ $\mathrm{cm}^{3}$ per minute. These adsorption rate constants are a little larger than those of Brevibacterium phages.

Effects of inorganic and organic cofactors on adsorption rate constant $(K)$. Effects of inorganic and organic cofactors on adsorption of the phages, P465, P468II and Ap85III, were investigated. Experiments were made using the dialysed phages to avoid the contamination of monovalent or divalent cation. The dialysed phages were diluted respectively with 0.01 м Tris-casein (0.01\%) buffer $(\mathrm{pH} 7.5)$ containing to $10^{-2} \mathrm{M}$ to $10^{-3} \mathrm{M}$ monovalent or divalent cations, $0.2 \%$ casamino acid (vitaminfree, Nissui Seiyaku Co.), 5\% vitamin mixture $^{*}$ and $100 \mu \mathrm{g} / \mathrm{ml}$ tryptophan, each to contain $3 \times 10^{5}$ PFU per $\mathrm{ml}$; the diluted phages were each mixed with bacterial suspension at the M.O.I. of 0.001 . Then, unadsorbed free

7) A. Gratia, Compt. Rend. Soc. Biol., 133, 702 (1940).

8) P M. Rountree, J. Gen. Microbiol., 5, 673 (1951).

9) T. T. Puck, A. Garen and J. Cline, J. Expt. Med., 93, 65 (1951).

10) L. W. Barksdale and A. M. Pappenheimer, J. Bacteriol., 67, 220 (1954).

11) E. B. Collins, F. E. Nelson and C. E. Parmelee, ibid., 60, 533 (1950).

12) M. Delbrück, idid., 56, 1 (1948).

13) T. F. Anderson, ibid., 55, 637 (1948).

14) T. F. Anderson, $J$. Cellular Comp. Physiol., 25, 17 (1945).

* It consists of Ca-pantothenate, riboflavin, thiamine. $\mathrm{HCl}$, $p$-aminobenzoic acid, pyridoxine $\mathrm{HCl}$, pyridoxal. $\mathrm{HCl}$, folic acid, biotin, niacin, adenine, guanine, uracil and xanthine.
TABLE II. EFFECT OF ADSORPTION COFACTORS oN STability of Dialysed Phage IN TRIS-CASEIN BUFFER

\begin{tabular}{|c|c|c|c|c|}
\hline \multirow{2}{*}{ Cofactor } & \multirow{2}{*}{ Added conc. } & \multicolumn{3}{|c|}{ Survival \% } \\
\hline & & $\mathrm{P} 465$ & P468II & Ap85III \\
\hline $\mathrm{KCl}$ & $0.01 \mathrm{M}$ & 89.5 & 91.5 & 67.8 \\
\hline $\mathrm{NaCl}$ & 0.01 & 100.8 & 97.4 & 85.1 \\
\hline$\left(\mathrm{NH}_{4}\right)_{2} \mathrm{SO}_{4}$ & 0.01 & 92.5 & 84.5 & 87.7 \\
\hline $\mathrm{CaCl}_{2}$ & 0.01 & 104.7 & 100.5 & 90.1 \\
\hline $\mathrm{MgCl}_{2}$ & 0.01 & 96.9 & 97.2 & 93.4 \\
\hline $\mathrm{MnCl}_{2}$ & 0.001 & 86.3 & 104.5 & 89.0 \\
\hline $\mathrm{FeSO}_{4}$ & 0.001 & 0 & 0 & 0 \\
\hline $\mathrm{ZnSO}_{4}$ & 0.001 & 70.5 & 96.8 & 90.4 \\
\hline $\mathrm{CoSO}_{4}$ & 0.001 & 94.7 & 101.5 & 81.4 \\
\hline $\mathrm{CuSO}_{4}$ & 0.001 & 33.6 & 48.5 & 23.6 \\
\hline $\mathrm{BaCl}_{2}$ & 0.001 & 98.9 & 100 & 93.5 \\
\hline Tryptophan & $100 \mu \mathrm{g} / \mathrm{ml}$ & 98.0 & 97.1 & 83.8 \\
\hline Casamino aci & id $0.2 \%$ & 99.3 & 94.9 & 96.3 \\
\hline $\begin{array}{l}\text { Vitamin } \\
\text { mixture }\end{array}$ & $5 \%$ & 99.1 & 97.3 & 86.6 \\
\hline $\begin{array}{l}\text { Control: } \\
\text { Tris-casein }\end{array}$ & $n$ buffer & 100 & 100 & 100 \\
\hline
\end{tabular}

Incubation: Shaken for $30 \mathrm{~min}$, at $30^{\circ} \mathrm{C}$ in $0.01 \mathrm{M}$ Tris-casein $(0.01 \%)$ buffer (pH 7.5) containing respective cofactor.

Initial titer of dialysed phage was $3 \times 10^{5} \mathrm{PFU}$ per ml.

phages and infected bacteria were assayed after shaking for 10 minutes at $30^{\circ} \mathrm{C}$ for adsorption, and the adsorption rate constant, $K$, was calculated.

Inactivation of free phages by various salts, vitamin or amino acids, which were used as cofactors to study the effect on the adsorption of the phages, was previously tested under the same condition as in adsorption; and the results are given in Table II. The other cofactors except $\mathrm{FeSO}_{4}$ and $\mathrm{CuSO}_{4}$ scarcely affected on the free phages, but, because both $\mathrm{FeSO}_{4}$ and $\mathrm{CuSO}_{4}$ inactivated free phages considerably, adsorption rate constant was calculated from the number of infected bacteria. Table III shows that for the three phages the various cofactor supplements had significant effect on the adsorption rate constants. The adsorption rate constants, $K$, of the phages, P465 and Ap85III, increased remarkably in a 
TABLE III. EFFECT OF COFACTORS ON ADSORPTION OF PHAGE IN $B r$. lactofermentum

No. 2256-Dialyzed Phage System

\begin{tabular}{|c|c|c|c|c|}
\hline \multirow[t]{2}{*}{ Cofactor } & \multirow[t]{2}{*}{ Conc. } & \multicolumn{3}{|c|}{$\begin{array}{l}\text { Adsorption rate constant } \\
\qquad K\left(\times 10^{-11}\right)\end{array}$} \\
\hline & & P465 & P468II & Ap85III \\
\hline $\mathrm{K}^{+}(\mathrm{KCl})$ & $0.01 \mathrm{M}$ & 0.03 & 0 & 0.44 \\
\hline $\mathrm{Na}++(\mathrm{NaCl})$ & 0.01 & 0.33 & 0 & 1.28 \\
\hline $\mathrm{NH}_{4}+\left(\left(\mathrm{NH}_{4}\right)_{2} \mathrm{SO}_{4}\right)$ & 0.01 & 0.17 & 0 & 0.77 \\
\hline $\mathrm{Ca}^{++}\left(\mathrm{CaCl}_{2}\right)$ & 0.01 & 16.4 & 0.31 & 7.45 \\
\hline $\mathrm{Mg}^{++}\left(\mathrm{MgCl}_{2}\right)$ & 0.01 & 9.84 & 0.12 & 4.67 \\
\hline \multirow[t]{2}{*}{$\mathrm{Ca}^{++}$and $\mathrm{Mg}^{++}$} & 0.01 each & 12.3 & 1.19 & 5.95 \\
\hline & $0.001 n$ & 18.7 & 2.11 & 8.10 \\
\hline $\mathrm{Mn}^{++}\left(\mathrm{MnCl}_{2}\right)$ & 0.001 & 0.33 & 0.12 & $0.5 \mathrm{I}$ \\
\hline $\mathrm{Fe}^{++}\left(\mathrm{FeSO}_{4}\right)$ & 0.001 & 0.26 & 0 & 0.11 \\
\hline $\mathrm{Zn}^{++}\left(\mathrm{ZnSO}_{4}\right)$ & 0.001 & 0.23 & 0 & 0.58 \\
\hline $\mathrm{Co}^{++}\left(\mathrm{CoSO}_{4}\right)$ & 0.001 & 0.53 & 0 & 0.15 \\
\hline $\mathrm{Cu}^{++}\left(\mathrm{CuSO}_{4}\right)$ & 0.001 & 0.40 & 0 & 0.27 \\
\hline $\mathrm{Ba}^{++}\left(\mathrm{BaCl}_{2}\right)$ & 0.001 & 0.10 & 0 & 0.22 \\
\hline \multirow[t]{2}{*}{ Tryptophan } & $50 \mu \mathrm{g} / \mathrm{ml}$ & 0.14 & 0 & 0.41 \\
\hline & $100 \quad "$ & 0.08 & 0 & 0.29 \\
\hline Casamino acid & $0.20^{\circ}$ & 0.54 & 0 & 0.51 \\
\hline Vitamin mixture & $5 \%$ & 0.07 & 0 & 0.31 \\
\hline \multicolumn{2}{|c|}{$\begin{array}{l}\mathrm{Ca}^{++} \text {and } \mathrm{Mg}^{++}, 0.001 \mathrm{M} \text { each } \\
\text { plus tryptophan } 100 / \mu \mathrm{g} / \mathrm{ml}\end{array}$} & - & 3.34 & - \\
\hline or casamino acid & 0.20 & - & 4.94 & - \\
\hline $\begin{array}{l}\text { or vitamin } \\
\text { mixture }\end{array}$ & 8 & - & 3.56 & 一 \\
\hline \multicolumn{2}{|l|}{$\begin{array}{l}\text { Control: Tris- } \\
\text { casein buffer }\end{array}$} & 0.14 & 0 & 0.62 \\
\hline \multicolumn{2}{|l|}{$\mathrm{S}$ medium } & 5.77 & 5.85 & 8.55 \\
\hline
\end{tabular}

Adsorption was carried out for $10 \mathrm{~min}$. at $30^{\circ} \mathrm{C}$ in $0.01 \mathrm{M}$ Tris-casein $(0.01 \%)$ buffer ( $\mathrm{pH} 7.5$ ) containing respective cofacter.

$B / P$ ratio: 0.001

concentration $\left(10^{-2} \mathrm{M}\right)$ of either $\mathrm{Ca}^{++}$or $\mathrm{Mg}^{++}$, and the other cofactors did not affect. However, the adsorption of the phage P468II increased in a concentration $\left(10^{-2}\right.$ to $\left.10^{-3} \mathrm{M}\right)$ of both $\mathrm{Mg}^{++}$and $\mathrm{Ca}^{++}$, and, by adding tryptophan, amino acids or vitamins besides above cofactors, it further increased. Accordingly, from the data it is obvious that the phages, P465 and Ap85III, have specific requirement for either $\mathrm{Ca}^{++}$or $\mathrm{Mg}^{++}$; and the phage P468II requires both of them for the adsorption onto the host cell. This is important from a practical standpoint. In many cases the cationic requirement is known to involve a step subsequent to adsorption, ${ }^{151}$ and, in the case of the phage $\mathrm{T} 5$, the step is definitely penetration of the phage DNA into the host cell. ${ }^{16,171}$ In addition to the ionic requirements, there is one case of a relatively specific requirement for an organic cofactor for adsorption, as described on the tryptophan-requiring strains of the phage $T 4 .^{12,131}$

Effect of temperature on adsorption of the phages, $\mathbf{P 4 6 5}$ and $\mathbf{P 4}$. Effect of temperature on the adsorption of the phages, P465 and P4, was investigated. The experiments were carried out at various temperatures ranging from $25^{\circ} \mathrm{C}$ to $40^{\circ} \mathrm{C}$ in nutrient broth, and the $K$ value was calculated from the unadsorbed free phages assayed $10 \mathrm{~min}$. later. The results are given in Table IV. Both P465 and P4 were adsorbed at the maximum velocity at $32^{\circ} \mathrm{C}$, but the adsorption of $\mathrm{P} 4$ was characteristic at the temperatures above $35^{\circ} \mathrm{C}$.

The $K$ value calculated from unadsorbed free phages differs quite from that from number of infected bacteria, i.e., the former is the largest at $40^{\circ} \mathrm{C}$ whereas the latter nearly zero, because adsorbed $\mathrm{P} 4$ failed to form the

TABLE IV. EFFEct OF TEMPERATURE ON ADSORPTION

\begin{tabular}{clc}
$\begin{array}{c}\text { Temperature } \\
\left({ }^{\circ} \mathrm{C}\right)\end{array}$ & \multicolumn{2}{c}{$K\left(\times 10^{-10}\right)$} \\
25 & $\mathrm{P} 465$ & $\mathrm{P} 4$ \\
28 & 1.10 & 1.85 \\
30 & 1.69 & 2.29 \\
32 & 2.03 & 2.13 \\
35 & 2.31 & $2.20(0.88)$ \\
40 & 1.89 & $1.17(0.05)$
\end{tabular}

Adsorption was carried out for $10 \mathrm{~min}$. at $30^{\circ} \mathrm{C}$ in nutrient bouillon.

$P / B$ ratio: 0.001

Number in parentheses shows the $K$ values calculated from the number of infected bacteria.

15) M. H. Adams, "Bacteriophages," Interscience Publishers, N.Y., 1959, pp. 141 \& 234 .

16) R. Wahl, Ann. Inst. Pasteur, 72, 73 (1946).

17) S. E. Luria and D. L. Steiner, J. Bacteriol., 67, 635 (1954). 
plaque above $35^{\circ} \mathrm{C}$. This probably means that at the temperature over $35^{\circ} \mathrm{C}$ unadsorbed free $\mathrm{P} 4$ is inactivated, or that $\mathrm{P} 4$ adsorbed onto the host cell causes the abortive infection on a stage of the multiplication, or that both may occur. In fact, as described in previous

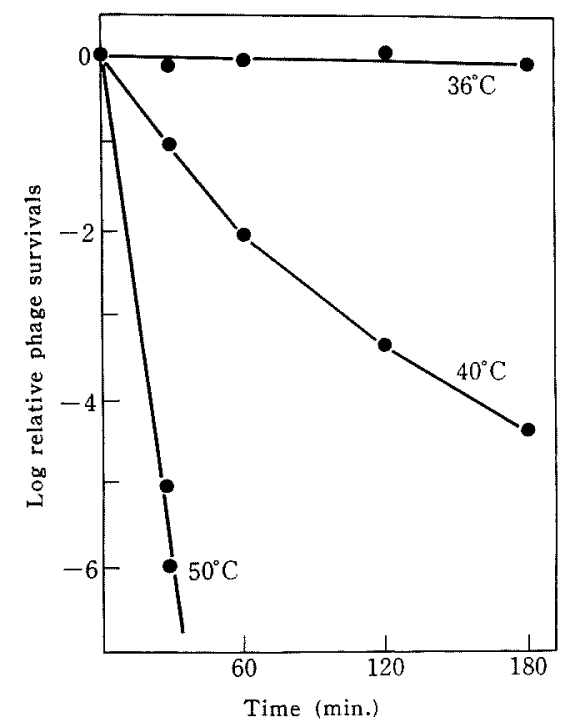

FIG. 2. Effect of Temperature on the Free P4 Phage.

Incubation was carried out in nutrient bouillon (pH 7.4).

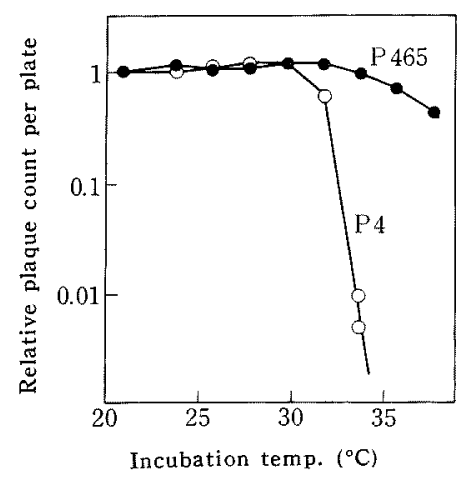

FIG. 3. Effect of Incubation Temperature of Plate on Plaque Formation.

Doubled-layed plates were incubated at various temperatures for 20 hours. paper $^{181}$ that $\mathrm{P} 4$ is labile to temperature, free phage $\mathrm{P} 4$ was stable below $36^{\circ} \mathrm{C}$ but rapidly inactivated at $40^{\circ} \mathrm{C}$ (Fig. 2). Although the effect of temperature on the multiplication of above phage will be discussed later, its plaqueforming ability was suppressed at above $32^{\circ} \mathrm{C}$ as shown in Fig. 3, when the plates, which were double-layed with phages and the host cells, were incubated at various temperatures, whereas the host bacterium and the phage P465 grew.

Furthermore, investigation on the effect of the host cell, i.e., the $\mathrm{B}_{2}$ cells grown in biotindeficient medium $(20 \mu \mathrm{g} / \mathrm{l})$ and the $\mathrm{B}_{50}$ cells grown in biotin-sufficient medium $(50 \mu \mathrm{g} / \mathrm{l})$, on the phage adsorption were made. A large amount of evidence has indicated that the action of biotin would be closely related to the metabolism of fatty acids, to the cellular

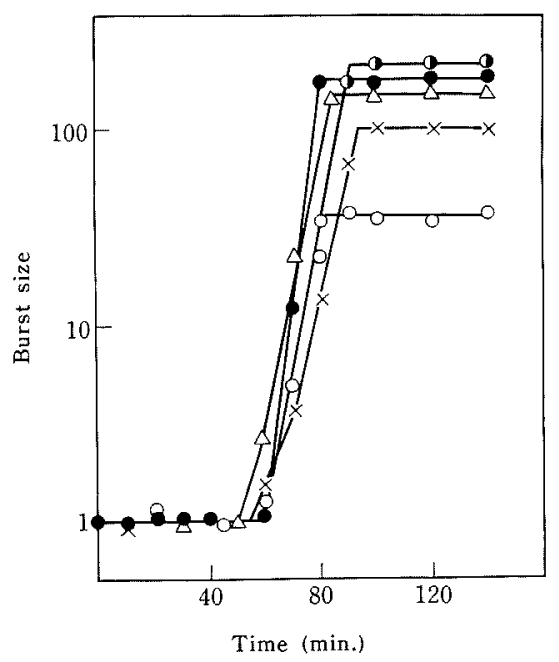

FIG. 4. One-Step Growth Curves of Four Phages.

Incubation: Shaken at $30^{\circ} \mathrm{C}$ in $\mathrm{G}_{5} \mathrm{~B}_{2}$ medium after adsorption for $10 \mathrm{~min}$. at $30^{\circ} \mathrm{C}$. M.O.I. $=0.01$

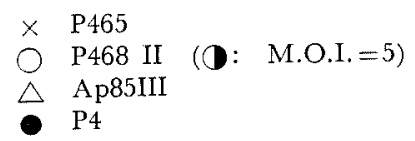

18) T. Oki, T. Matsui and A. Ozaki, This Journal, 31, 1040 (1967). 
permeability and the structure of cell wall in glutamic acid-producing bacteria. ${ }^{19-24)}$ However there was little difference in the adsorption rate constants between the $B_{2}$ and $B_{50}$ cells. That is, the $K$ value of the phage $\mathrm{P} 465$ was $2.78 \times 10^{-10}$ on the $B_{2}$ cells and $2.94 \times 10^{-10}$ on the $\mathrm{B}_{50}$ cells.

Determination of latent period and burst size by means of one-step growth experiments. Typical one-step growth curves of the four phages are presented in Fig. 4. The curves gave the values for the latent period, the average burst size and the rise period, as given in Table $V$. Among the four phages, differences were notable in both the average burst size (31 $160)$ and the rise period ( $24 \sim 48 \mathrm{~min}$.$) , but in$ the latent period the difference of values (47 59 min.) was very small. The resulting

Table V. Burst Size and Latent Period of Four Phages by ONE-STEP GRowth EXPERIMENTS

$\begin{array}{lcccc}\text { Phage } & & \begin{array}{c}\text { Latent } \\ \text { period } \\ \text { (min.) }\end{array} & \begin{array}{c}\text { Rise } \\ \text { period } \\ \text { (min.) }\end{array} & \begin{array}{c}\text { Burst } \\ \text { size }\end{array} \\ \text { P465 } & \mathrm{B}_{2} & 50 & 48 & 98 \\ \text { P468II } & \mathrm{B}_{50} & 51 & 39 & 100 \\ & & 53 & 29 & 31 \\ & \text { M.O.I. }=2 & 58 & 35 & 80 \\ \text { Ap85III } & \text { M.O.I. }=5 & 59 & 38 & 160 \\ \text { P4 } & & 57 & 24 & 145 \\ & & 47 & 40 & 126\end{array}$

Each value is an average of five experiments.

Incubation: Shaken at $30^{\circ} \mathrm{C}$ in $\mathrm{G}_{5} \mathrm{~B}_{2}$ medium after adsorption for $10 \mathrm{~min}$. at $30^{\circ} \mathrm{C}$.

M.O.I.: 0.01

$\mathrm{B}_{2}: \quad \mathrm{B}_{2}$ cell (grown in biotin-deficient medium, 2 $\mu \mathrm{g} / 1)-\mathrm{G}_{5} \mathrm{~B}_{2}$ medium system.

$B_{50}$ : $B_{50}$ cell (grown in biotin-sufficient medium, $50 \mu \mathrm{g} / 1)-\mathrm{G}_{5} \mathbf{B}_{50}$ medium system.

19) W. Trager, J. Bacteriol., 56, 195 (1948).

20) I. Shiio, S. Otsuka and M. Takahashi, J. Biochem., 51, 56 (1962).

21) M. Shibukawa and T. Ohsawa, This Journal, 30, 750 (1966).

22) K. Takinami, Y. Yamada and H. Okada, This Journal, 31, 223 (1967).

23) K. Kono, Y. Iijima, T. Oki, N. Miyachi and A. Ozaki, Amino Acid and Nucleic Acid, 11, 99 (1965).

24) I. Shiio, S. Otsuka and N. Katsuya, J. Biochem., 53, 333 (1963). values (average burst size and latent period) for $\mathrm{P} 465$ in these data (Table V) are remarkably different from the results given in the previous data. ${ }^{3 \prime}$ This may be due to unsatisfactory procedural conditions in experiments; i.e., in the previous report, ${ }^{3 \prime}$ antiphage serum was not used and the number of experiments was limited only to a few. Seto et al. ${ }^{2}$ estimated the latent period as 40 to 140 minutes and the burst size 15 to 150 on five phages of Mic. ammoniaphilum under their conditions. It seems that there is great variety in the latent period and the average burst size among the phages of L-glutamic acid-producing bacteria.

Delbrück ${ }^{251}$ and $\mathrm{Heden}^{26}$ indicated that the latent period and the burst size are strongly affected by the physiological state of the host cell. However, in the one-step growth experiments with $\mathrm{P} 465$, the physiological dif-

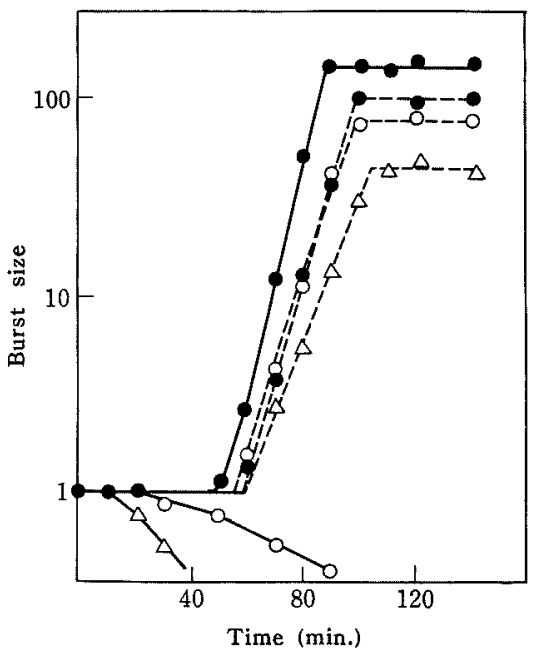

FIG. 5. Effect of Temperature on Multiplication of Phages $\mathrm{P} 465$ and $\mathrm{P} 4$.

Incubation: Shaken at indicated temperature (O: $30^{\circ} \mathrm{C}, \bigcirc: 34^{\circ} \mathrm{C}, \triangle: 36^{\circ} \mathrm{C}$ ) in $\mathrm{G}_{5} \mathrm{~B}_{2}$ medium after adsorption for $10 \mathrm{~min}$. at $30^{\circ} \mathrm{C}$.

$$
\text { - --:: P465 —: P4 }
$$

25) M. Delbrück, Biol. Revs. Cambridge Phil. Soc., 21, 30 (1946).

26) C. Heden, Acta. Pathol. Microbiol. Scand., Suppl. No. 88. (1951). 
ference of the host cells between the $\mathrm{B}_{2}$ and $B_{50}$ cells has not influenced upon both the latent period and the burst size, but only the rise period was shortened in the biotin-sufficient cells (Table V). With the phage P468II, the average burst size varied with the multiplicity of infection; that is, 30 with the single infection, 80 with M.O.I. 2 and 160 with M.O.I. 5, but the latent period did not change.

Effect of temperature on the latent period and the burst size. The one-step growth experiments were carried out at the temperatures of 30,34 and $36^{\circ} \mathrm{C}$ with the phages, P465 and $\mathrm{P} 4$. The results are given in Fig. 5. Although the temperature generally affects the latent period of the generation time of bacteria, ${ }^{1,271}$ the latent period of the phage $\mathrm{P} 465$ was scarcely influenced at $36^{\circ} \mathrm{C}$. On the contrary, the growth of the phage $\mathrm{P} 4$ was completely suppressed even at $34^{\circ} \mathrm{C}$, although the

27) M. Hongo, T. Miyamoto and A. Murata, This Journal, 30, 500 (1966). host bacteria was capable of the full growth at the same temperature. This conformed with the results given in Fig. 3, in which the plaque-forming ability of the phage $\mathrm{P} 4$ was extremely suppressed at above $32^{\circ} \mathrm{C}$, and it may be explained by such a temperature sensitivity of phages as was examined with ts mutant, which was developed by Campbell ${ }^{281}$ and Edgar et al. ${ }^{29,301}$

Acknowledgements. The authors are greatly indebted to Dr. H. Ozeki of the National Institute of Health for his kind guidance and suggestions during the course of this investigation. Thanks are also due to Mr. M. Suzuki, President, Dr. N. Miyachi, Vice-Director of our laboratories, and Mr. T. Matsui of the Yatsushiro Faculty, of Sanraku-Ocean Co., Ltd., for their constant encouragement throughout the course of this work.

28) A. Campbell, Virology, 14, 22 (1961).

29) P.S. Edgar, G.H. Denhardt and R.H. Epstein, Genetics, 49, 635 (1964).

30) P.S. Edgar and I. Lielansis, ibid., 49, 649 (1964). 